\title{
An Early Triassic (Dienerian) microgastropod assemblage from the Salt Range, Pakistan and its implication for gastropod recovery from the end-Permian mass extinction
}

\author{
Alexander Nützel, David Ware, Hugo Bucher, Michael Hautmann, GHazala RoOHI, \\ KHALIL UR-REHMAN \& AMIR YASEEN
}

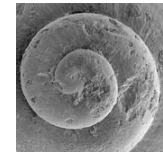

\begin{abstract}
A single limestone sample from the Early Triassic (late Dienerian) of the Salt Range in Pakistan has yielded numerous small gastropods (smaller $2 \mathrm{~mm}$ ), few bivalves and abundant ammonoids. The limestone is interpreted as a tempestite. Many of the gastropods are extremely well-preserved including protoconch preservation and micro-ornaments. Five species of gastropods are present: (1) isolated larval shells representing a neritimorph taxon of the family Trachyspiridae, (2) early juvenile and larval specimens of the caenogastropod Strobeus pakistanensis, (3) the new caenogastropod species Coelostylina hydrobiformis Nützel \& Ware, (4) the new heterobranch genus and species Eographis microlineata Nützel \& Ware representing the earliest occurrence of the extant family Hyalogyrinidae (Valvatoidea), (5) the heterobranch Sinuarbullina sp., a genus which originates in the Early Triassic and has also been reported from China, Spitsbergen and the US. Three genera (trachyspirid, Strobeus and Coelostylina) represent survivors from the end-Permian mass extinction whereas Eographis and Sinuarbullina have their earliest known occurrence in the Early Triassic. Eographis is the first Early Triassic genus for which coaxial larval heterostrophy is shown. Together with the Devonian genus Palaeocarboninia and the Carboniferous genus Heteroaclisina, it witnesses a high age of Ectobranchia (living families Hyalogyrinidae, Valvatidae, Cornirostridae and Xylodisculidae). This supports the assumption that this group is the first extant offshoot of the Heterobranchia. The studied assemblage is strongly dominated by Strobeus pakistanensis. The small size of the gastropods reflects their ontogenetic stage (early juvenile and larval shells) as well as a small adult size in some of the species. Most of the present gastropods had planktotrophic larval development providing further evidence against the hypothesis that the end-Permian mass extinction event selected against larval planktotrophy. Failure to grow to a larger size or to perform metamorphosis suggests unfavourable living conditions in the source community probably due to oxygen deficiency prior to transport by storm. Size sorting is seen as less likely because the limestone is poorly sorted with relatively large ammonoids being present in considerable numbers. The studied sample yielded also three bivalve taxa amongst them two species representing the genera Leptochondria and Crittendenia. - Key words: Gastropoda, Bivalvia, Early Triassic, Recovery, end-Permian extinction, protoconchs.
\end{abstract}

NÜtzel, A., Ware, D., Bucher, H., Hautmann, M., Roohi, G., UR-Rehman, K. \& Yaseen, A. 2018. An Early Triassic (Dienerian) microgastropod assemblage from the Salt Range, Pakistan and its implication for gastropod recovery from the end-Permian mass extinction. Bulletin of Geosciences 93(1), 56-70 (7 figures). Czech Geological Survey, Prague. ISSN 1214-1119. Manuscript received June 6, 2017; accepted in revised form November 20, 2017; published online March 28, 2018; issued March 31, 2018.

\begin{abstract}
Alexander Nützel, Bayerische Staatssammlung für Paläontologie und Geologie, Ludwig-Maximilians-University Munich, Department für Geo- und Umweltwissenschaften, Paläontologie und Geobiologie, Geobio-Center ${ }^{L M U}$, Richard Wagner Str. 10, 80333 München, Germany; a.nuetzel@lrz.uni-muenchen.de • David Ware, Museum für Naturkunde, Leibniz-Institut für Evolutions- und Biodiversitätsforschung, Invalidenstraße 43, 10115 Berlin, Germany \& Paläontologisches Institut und Museum, Universität Zürich, Karl Schmid-Strasse 4, 8006 Zürich, Switzerland; david.ware@mfn.berlin・Hugo Bucher \& Michael Hautmann, Paläontologisches Institut und Museum, Universität Zürich, Karl Schmid-Strasse 4, 8006 Zürich, Switzerland; hugo.fr.bucher@pim.uzh.ch, michael.hautmann@pim.uzh.ch - Ghazala Roohi, Khalil Ur-Rehman \& Amir Yaseen, Earth Science Division, Pakistan Museum of Natural History, Garden Avenue, Shakarparian, Islamabad 44000, Pakistan; roohighazala@yahoo.com, reman_geol@yahoo.com, yaseenaamir@hotmail.com
\end{abstract}




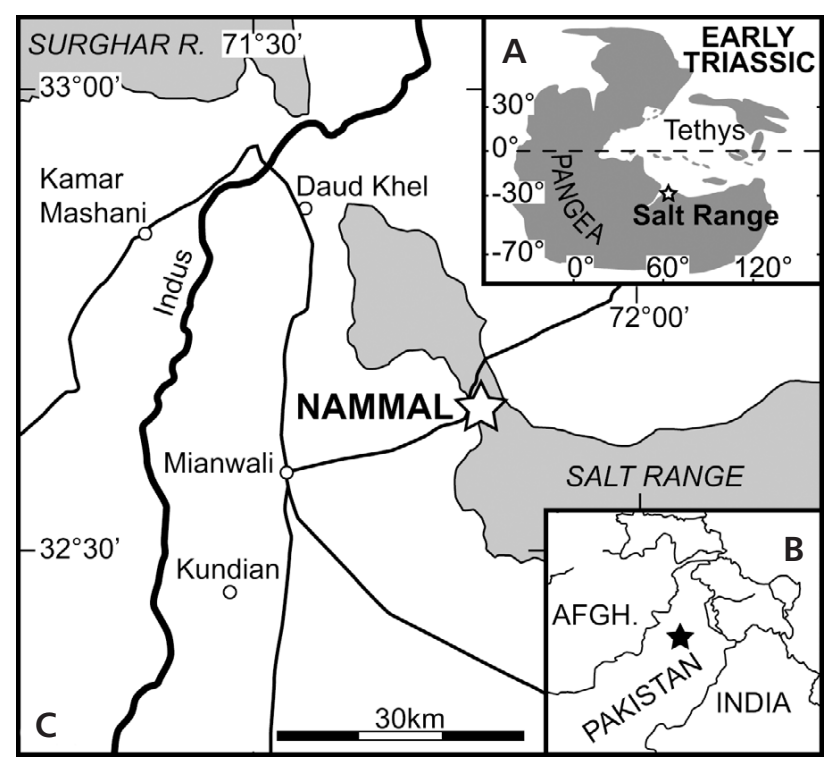

Figure 1. Locality maps (modified from Ware et al. in press). - A - palaeogeographical map of the Early Triassic with the palaeoposition of the Salt Range (modified from Brayard et al. 2006). - B - map of Pakistan with position of the studied area (black star). - C - location map of Nammal Nala in the Salt Range (modified after Brühwiler et al. 2012).

The Salt Range hosts important Permian-Triassic marine sections which have yielded abundant ammonoids that provide a well-studied stratigraphic framework (e.g. Waagen 1895; Brühwiler et al. 2010, 2011, 2012; Ware et al. 2015, in press). Kaim et al. (2013) provided the first detailed study of Early Triassic (Smithian/Spathian) gastropods from the Salt Range. These authors reported five gastropod species: the bellerophontoid Warthia hisakatsui Murata, 1981, the neritimorph Naticopsis sp., two new species representing the caenogastropod genus Strobeus ( $S$. batteni and S. pakistanensis) as well as the caenogastropod Coelostylina sp. Most of these species were present with more or less fully-grown individuals in the centimetre-size range except for Coelostylina sp. and early juveniles of the genus Strobeus. In the course of the study of Dienerian ammonoids from the Salt Range, one of us (DW) discovered mass accumulations of tiny $(<2 \mathrm{~mm})$ gastropods in the matrix between the ammonoids. These highly abundant gastropods are very well preserved and are reported in the present contribution.

\section{Geological setting}

The Salt Range is a low mountain range situated about $150 \mathrm{~km} \mathrm{SSW}$ of Islamabad (Fig. 1B). In the Early Triassic, it was situated in Southern Tethys, at a palaeo-latitude of ca. $30^{\circ} \mathrm{S}$ (Fig. 1A). The Salt Range constitutes a key locality for the study of Early Triassic marine faunas due to its extensive outcrops of highly fossiliferous marine sediments. Nammal Nala is one of the classical localities for the study of the Permian-Triassic of the Salt Range and has been extensively studied by e.g. Kummel (1966), Kummel \& Teichert (1970), Guex (1978), Hermann et al. (2011a), Brühwiler et al. (2012), Wasmer et al. (2012) and Ware et al. (in press). It is a small canyon situated ca. $25 \mathrm{~km}$ ENE of Mianwali (Fig. 1A).

In the Salt Range, the Early Triassic is represented by the Mianwali Formation, a ca. $120 \mathrm{~m}$ thick succession of limestone and siliciclastic marine sediments. This formation unconformably overlies the late Permian Chiddru Fm. In Nammal Nala it is conformably overlain by the terrestrial Middle Triassic Tredian Fm. The Mianwali Fm. is usually subdivided into seven units (e.g. Guex 1978) of which only the stratigraphically third, the Ceratite Marls (middle Dienerian-early Smithian), is relevant here. In Nammal Nala, the Ceratite Marls represent a ca. $25 \mathrm{~m}$ thick shale interval with intercalated limestone and sandstone beds. Limestone beds are abundant in the lower third of the unit which is middle to late Dienerian in age. Limestone beds become rare in the two uppermost thirds of the units which are early Smithian in age while sandstone beds progressively become more abundant in the upper third. Hermann et al. (2011a, b; 2012a, b) showed that the middle to upper Dienerian part of the Ceratite Marls in Nammal recorded a local peak of anoxia. Romano et al. (2013) showed that it also coincided with a peak in temperature.

In addition to ammonoids (Ware et al. in press) and gastropods (partly described herein), bivalves are the most abundant fossils of the Ceratite Marls. In Nammal Nala, Claraia aurita (= Claraia concentrica) is very abundant in the lowermost part of the section but disappears abruptly ca. $0.8 \mathrm{~m}$ above the base of the Ceratite Marls. In contrast, Leptochondria and Bakevellia occur in high abundances throughout the Ceratite Marls. An additional bivalve taxon is represented by thin circular shells that might represent diagenetically flattened left valves of Crittendenia.

\section{Material and methods}

The gastropods described here all come from a single sample (NAM101d) from Nammal Nala, about $6 \mathrm{~m}$ above the base of the Ceratite Marls. The rock sample was crushed with a hammer on a steel plate and resulting rock gravel and powder was washed and sieved at a mesh size of $0.5 \mathrm{~mm}$. Part of the dried residue was picked quantitatively under a stereomicroscope. The best-preserved specimens were sputter-coated with gold and photographed under a SEM. One thin section was produced from the sample. The specimens and the thin section are housed at the Paläontologisches Institut und Museum, Universität Zürich (abbreviated PIMUZ). 

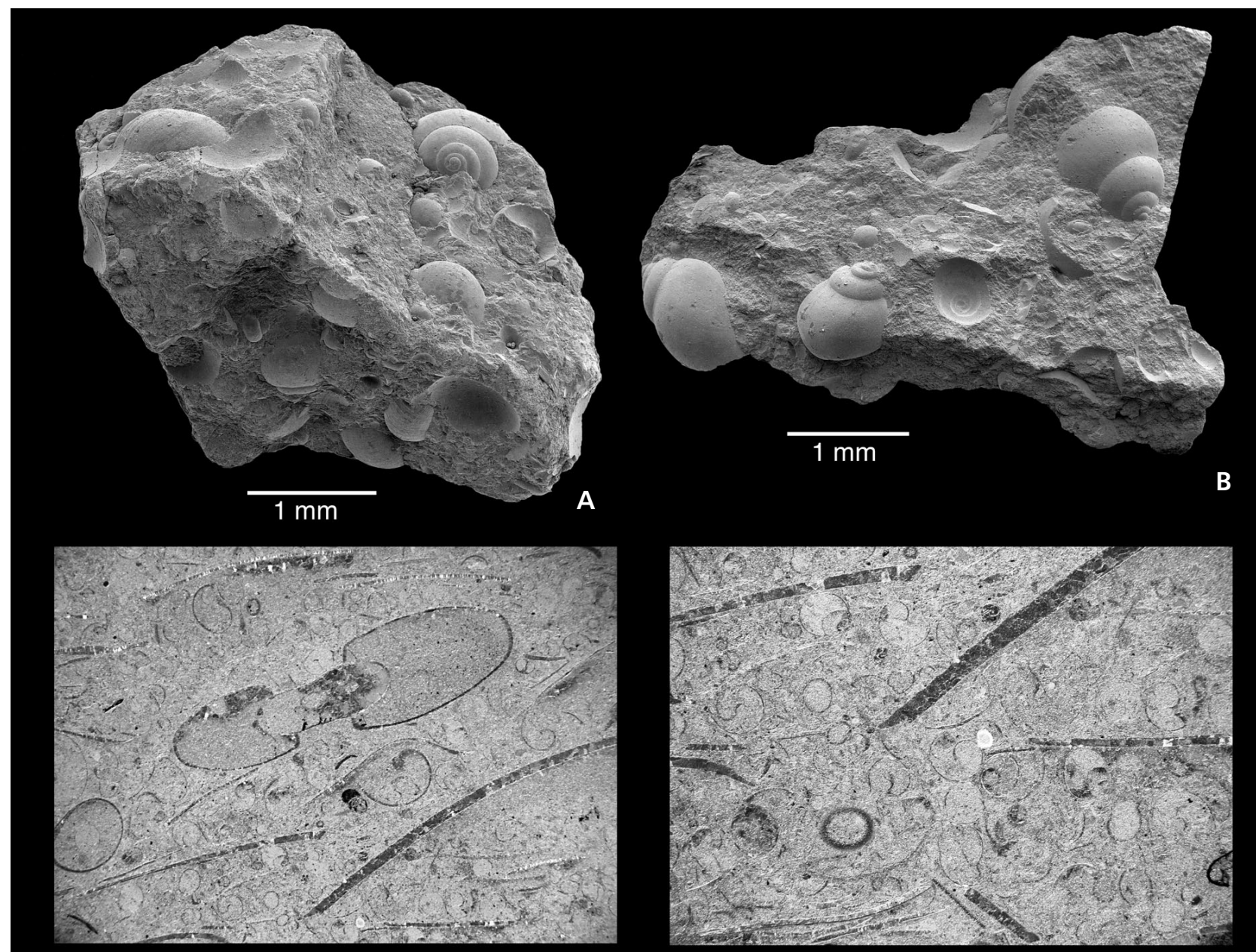

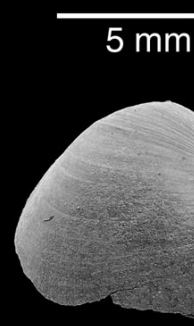

$1 \mathrm{~mm}$

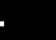

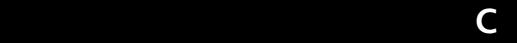

C

Figure 2. A, B • rock fragments showing several gastropods namely Strobeus pakistanensis; A - PIMUZ 32888, 32889; B - PIMUZ 32908-32910. - C, D - thin section of fossiliferous source rock of studied fauna; mollusc packstone with numerous gastropods, an ammonoid (C) and unidentified filaments probably representing bivalve or ammonoid fragments (D), PIMUZ 32945. - E, F - unidentified heteroconch species, PIMUZ 32937. • G, H - Leptochondria cf. albertii/curtocardinalis, PIMUZ 32931.

The exact stratigraphic position of the studied sample is indicated in Ware et al. (in press, fig. 4). It is late Dienerian in age and belongs to the Kingites davidsonianus Regional Zone of Ware et al. (in press) and zone DI-10 of Ware et al. (2015). Similar microgastropod assemblages were found in the middle and late Dienerian of several localities in the Salt Range as well as in Spiti (Himachal Pradesh, India). Microgastropods from the present sample are described here because of their excellent preservation. Like most limestone beds in the lower third of the Ceratite Marls from Nammal, sample NAM101d comes from a tempestite layer with highly variable facies. The base of the bed is usually a packstone with numerous ammonoids, bivalves and microgastropods, while its top is a floatstone with few ammonoids and rare bivalves and microgastropods. The facies of the sampled bed varies considerably laterally even 
across short distances (decimetres). The microgastropods described here come from the basal part of the bed, with numerous densely packed tiny gastropods $(<2 \mathrm{~mm}$; Fig. 2A-D). The numerous ammonoids are imbricated, the large ones are usually partially broken and large ammonoid shell fragments are frequent. The ammonoid fauna from this zone is described in detail in Ware et al. (in press). It is dominated by Koninckites khoorensis and Kingites davidsonianus is not rare. Other ammonoid species are very rare.

The paucispecific bivalve fauna found in larger rock fragments of the limestone bed (i.e. not crushed as described above) comprises three different taxa: (1) a weakly costellate Leptochondria similar to $L$. albertii and L. curtocardinalis (see discussion in Hautmann et al. 2013, p. 275), (2) poorly preserved left valves of Crittendenia and (3) a small heteroconch bivalve with unknown internal morphology, which bears some external resemblance to the Palaeozoic Cypricardella Hall, 1856 (e.g. Girty 1927, pl. 25, figs 60-78). The crushing method applied for preparation of the gastropods (see above) likely destroyed to a higher degree shells that are less isometric than gastropods, which might explain why bivalves are underrepresented in sample material which was prepared this way. However, two small bivalve specimens have been found among the small-sized gastropods, which can be assigned to Leptochondria cf. albertii/curtocardinalis (Fig. 2G, H) and the unidentified heteroconch species (Fig. 2E, F) described above.

\section{Results}

The studied limestone sample is highly fossiliferous with densely packed tiny gastropods $(<2 \mathrm{~mm})$ (Fig. 2A-D). It is a packstone with gastropods, bivalves and ammonoids. The crushed rock produced thousands of gastropod specimens representing five species. The gastropods are present as early juvenile specimens of usually larger growing species as well as small growing species and isolated larval shells. Juvenile Strobeus pakistanensis Kaim, Nützel, Hautmann \& Bucher, 2013 is by far the most abundant gastropod species forming more than $90 \%$ of the assemblage. Ammonoid and bivalve fragments are also present in the sample prepared by crushing but less abundant. However, a thin section shows that larger shell fragments of ammonoids and/or bivalves are common. The shell material is entirely recrystallized (aragonite to calcite). When breaking the rock sample, the fractures commonly formed along the fossil shells exposing superbly preserved specimens in great detail. The preparation (by crushing) preferably exposes round, isometric fossils and thus gastropods are overrepresented whereas flat objects such as bivalves may be underrepresented. On the other hand, both isolated fos- sils and thin section suggest that gastropods are by far the most abundant group present in the rock sample.

\section{Systematic Palaeontology}

This published work and the nomenclatural acts it contains have been registered in ZooBank:

http://zoobank.org/References/D4BA361F-DOFF-476F-8 425-B887D8616B0C. The classification used herein is based on Bouchet et al. (2017).

Class Gastropoda Cuvier, 1797

Order Neritimorpha Koken, 1896

Superfamily Neritoidea Rafinesque, 1815

Family Trachyspiridae Nützel, Frýda, Yancey \&

Anderson, 2007

\section{Trachyspiridae gen. et sp. ind.} Figure 3

Material. - Four specimens (PIMUZ 32886, 32912, 32924, 32932) from sample NAM101d, from Nammal Nala, about $6 \mathrm{~m}$ above the base of the Ceratite Marls (Ware et al. in press), Salt Range Pakistan, Early Triassic.

Description. - Shell broad; a larval shell fragment is $0.8 \mathrm{~mm}$ wide; a partly exposed larval shell comprising about three whorls is $0.9 \mathrm{~mm}$ high; rapidly expanding convex whorls with pending profile with periphery low on whorls near suture; whorls adpressed in a narrow subsutural zone; embryonic shell egg-shaped, smooth somewhat less than one whorl with a diameter of $0.14 \mathrm{~mm}$ and a diameter of first whorl of $0.17 \mathrm{~mm}$; following larval whorls with numerous narrow, collabral axial ribs; ribs strongly sinuous, strongly prosocyrt on visible part of larval whorls with zenith low on whorls; ribs forming a pronounced opisthocyrt sinus on base of larval whorls; in addition a non-collabral micro-ornament of fine spiral threads converging at mid-whorl is present on early larval whorls; teleoconch unknown.

Remarks. - Neritimorph larval shells with sinuous axial ribs have been reported repeatedly from the Late Palaeozoic (Kues \& Batten 2001 as Lunuluzona; Hua Zhang \& Erwin 2002 as Naticasinus; Bandel 2002a as Naticopsis; Nützel et al. 2007). Interpretations as a small-sized pleurotomarioid (Kues \& Batten 2001, Hua Zhang \& Erwin 2002, Kues et al. 2004) have been refuted by Nützel et al. (2007) who found this type of larval shell conjoined with a teleoconch with knobby, spiny ornament representing the genus Trachyspira. Meanwhile, it was also found in typical Trachydomia shells (AN, personal observation) - a widespread late Palaeozoic genus which is close to Trachyspira. Kaim (2009) reported this type of larval shell from the 

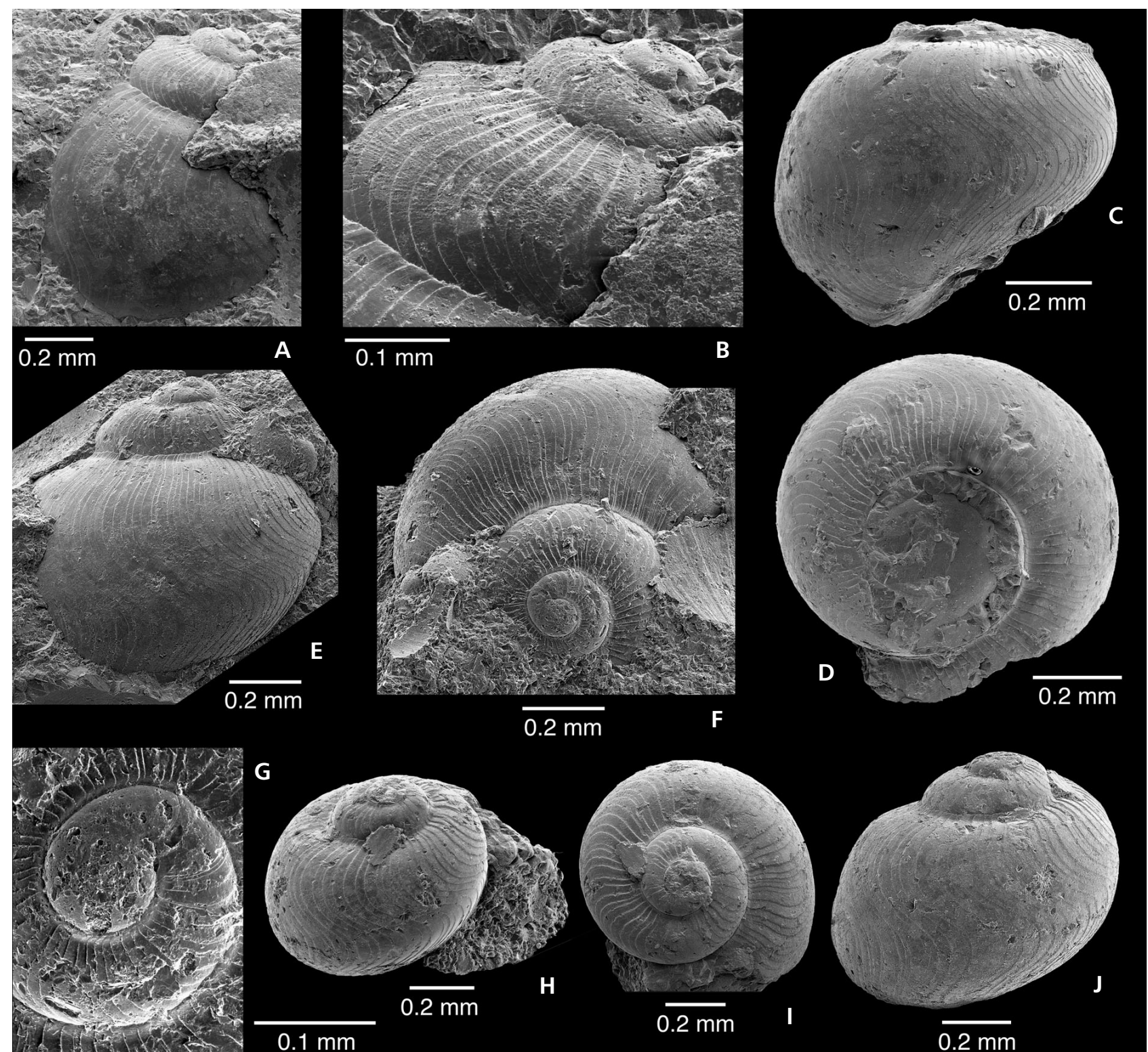

H

$0.1 \mathrm{~mm}$

\section{$\mathbf{F}$}
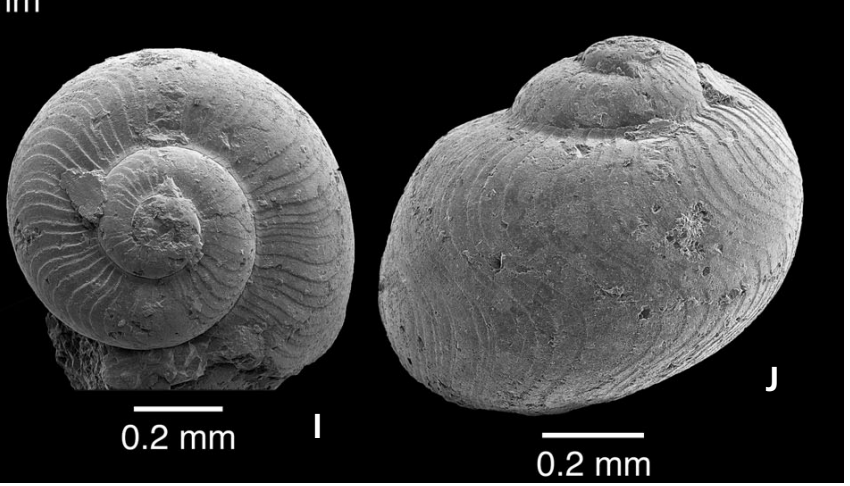

Figure 3. Trachyspiridae gen. et sp. ind.; A, B - PIMUZ 32886; C, D - PIMUZ 32912; E-G - PIMUZ 32924; H-J - PIMUZ 32932.

Early Triassic (early Dienerian) of Far East Russia (Abrek Bay). It is also present in the Smithian of the Western U.S. i.e. in the fauna from the Sinbad Limestone, Utah (AN, personal observation) that has been studied by Batten \& Stokes (1986). Bandel (2007) reported this type of larval shell from several Late Triassic neritimorph genera from the St. Cassian Formation (North Italy) which were placed in Naticopsidae by this author. Thus, the neritimorph group having this characteristic type of larval shell is now known from the Carboniferous to the Late Triassic and had a global distribution. Thus, this neritimorph group survived the end-Permian mass extinction and there are now several reports from the Early Triassic.
Subclass Caenogastropoda Cox, 1960

Superfamily Soleniscoidea Knight, 1931

Family Soleniscidae Knight, 1931

Genus Strobeus de Koninck, 1881

Type species. - Strobeus ventricosus de Koninck, 1881, Carboniferous, Belgium.

\section{Strobeus pakistanensis Kaim, Nützel,}

Hautmann \& Bucher, 2013

Figures 2A, B, 4

2005 Strobeus sp. - Nützel 2005, p. 441, fig. 7 left. 
* 2013 Strobeus pakistanensis sp. nov. - Kaim et al., p. 511, fig. $6 \mathrm{a}, \mathrm{b}, \mathrm{f}-\mathrm{h}, \mathrm{j}-\mathrm{l}$.

Material. - Numerous specimens (ca. 30 specimens studied with SEM: PIMUZ 32880, 32884, 32885, 32887-32890, 32893-32910, 32913-32915, 32917, 32918, 32920) from sample NAM101d, from Nammal Nala, about $6 \mathrm{~m}$ above the base of the Ceratite Marls (Ware et al. in press), Salt Range Pakistan, Early Triassic.

Description. - Only larval and juvenile specimens are at hand; largest specimen comprising 5-6 whorls, $1.7 \mathrm{~mm}$ high, $1.1 \mathrm{~mm}$ wide; shell bulbous-fusiform with dome-shaped, blunt but distinctly elevated spire; protoconch bulbous, consisting of about 4 rapidly increasing, distinctly convex whorls; initial whorl tightly coiled with a diameter of $0.11-0.14 \mathrm{~mm}$, without ornament; following larval shell of about 3-4 whorls, embracing at periphery; entire protoconch 1-1.2 $\mathrm{mm}$ high, $0.9 \mathrm{~mm}$ wide; larval whorls ornamented with extremely fine, irregular ornament of chevron-like axial threads only visible in extremely well-preserved specimens at high magnification; larval shell ends at faint orthocline line where micro-ornament ceases (marked with arrows in Fig. 4B, E-H); teleoconch smooth with orthocline growth lines and with whorls higher than in larval shell; teleoconch whorls slightly adpressed; base evenly rounded, anomphalous.

Remarks. - We have at hand thousands of larval or early juvenile shells with a maximum height of $1.7 \mathrm{~mm}$ from the single studied sample. They closely resemble the juvenile shell of S. pakistanensis (3.3 mm high) which was illustrated by Kaim et al. (2013, fig. 6f-h, j-1). However, this shell appears to be entirely smooth and lacks the axial micro-ornament present in our material. It is likely that this ornament is not preserved in the material studied by Kaim et al. (2013). The holotype of S. pakistanensis is a rather large specimen (18.8 mm high) with worn early whorls so that it is not entirely sure - although likely - whether the mentioned larval and early juvenile specimens represent this species. Strobeus pakistanensis was first reported from the upper Smithian of the Salt Range (Kaim et al. 2013). The present small specimens from the Salt Range resemble Strobeus shigetai Kaim, 2009 from Early Triassic of Primorye but differ in having a much blunter apex and in being more bulbous. Strobeus shigetai has the same type of axial micro-ornament that is present on the early whorls of the specimens studied here. However, this ornament was interpreted as being on the teleoconch by Kaim (2009); by con- trast, it is considered a larval shell ornament herein. It seems to be possible that this ornament represents also a larval ornament in Strobeus shigetai. It is obvious that Strobeus pakistanensis and $S$. shigetai are closely related as is suggested by its general shape and the characteristic micro-ornament of the early whorls - it is also present in soleniscoid species from the Smithian Sinbad Limestone of Utah (AN own observation). Orthostrophic caenogastropod larval shells that are smooth or only weakly ornamented have been reported for late Palaeozoic soleniscids by Nützel \& Hua Zhang (2005). These species have tightly coiled initial whorls as is also the case for the present Strobeus species.

The generic identity of Strobeus pakistanensis and S. shigetai as well as other similar species is not beyond doubt - the type species of Strobeus has a thick and continuous inductura (Knight 1941) which is absent or not preserved in the mentioned Early Triassic taxa. Moreover, the early whorls including the protoconch have not been reported for the type species of Strobeus. The Late Palaeozoic species which have been assigned to Strobeus by Bandel (2002a) have an openly coiled initial whorl and this is not the case in Strobeus pakistanensis and Strobeus shigetai. The status of this character is unknown for the type species of Strobeus. Therefore, the generic identity of these Early Triassic species and those from the late Palaeozoic as reported by Bandel (2002a) remains open.

The present specimens of Strobeus pakistanensis have a small diameter of the initial whorl of $0.12-0.14 \mathrm{~mm}$ followed by about three whorls which are interpreted here as larval shell that ends at a faint line forming the border to the inferred teleoconch (marked with arrows in Fig. 4B, E-H). These dimensions suggest larval planktotrophy for this species (see Nützel 2014). With a height of up to $1.2 \mathrm{~mm}$, the protoconch of Strobeus pakistanensis is rather large. However, there are several reports of larval shells in this size range from the Late Palaeozoic to early Mesozoic including examples representing Soleniscidae in which Strobeus is currently placed (Nützel \& Mapes 2001, Mapes \& Nützel 2009, Nützel 2014).

Superfamily unknown

Family Coelostylinidae Cossmann, 1909

\section{Genus Coelostylina Kittl, 1894}

Type species. - Melania conica Münster, 1841, Carnian (Late Triassic), Cassian Formation, northern Italy.

Figure 4. Strobeus pakistanensis; A-D - PIMUZ 32915; E-I - PIMUZ 32913, arrows indicating presumed end of larval shell; J - PIMUZ 32907; K - PIMUZ 32898; L - PIMUZ 32893; M - PIMUZ 32880. 


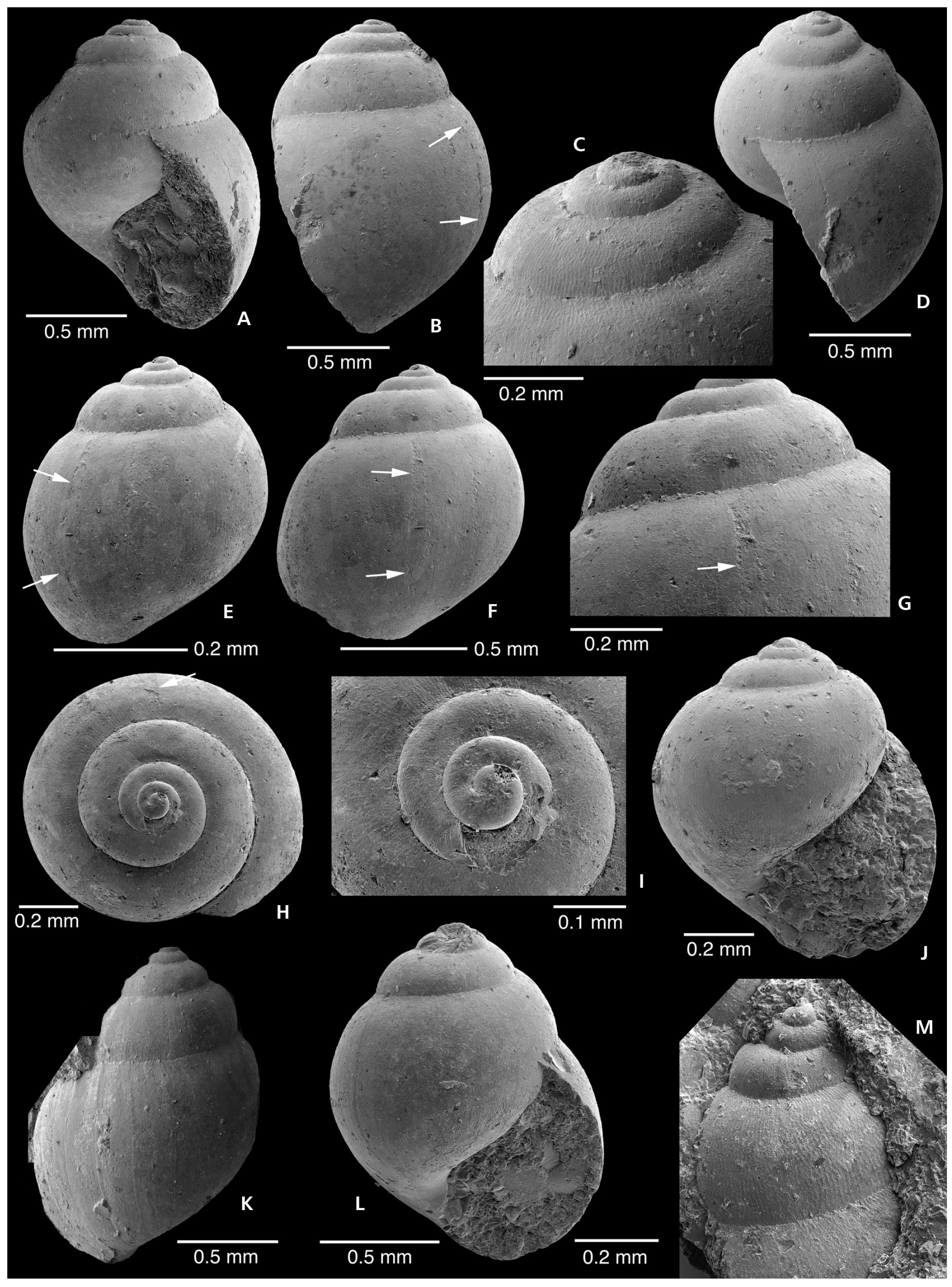




\section{Coelostylina hydrobiformis Nützel \& Ware sp. nov. Figure 5}

LSID. urn:lsid:zoobank.org:act:24095F5E-D50B-45E8-A 0B3-18F59AAA66A0

? 2013 Coelostylina sp. - Kaim et al., p. 512, fig. 7.

Types. - Holotype (PIMUZ 32926) and 12 paratypes (PIMUZ 32882, 32891, 32892, 32922, 32925, 32927. 32930, 32935, 32938, 32939, 32941, 32944).

Etymology. - After the modern gastropod genus Hydrobia which resembles the new species in shell shape.

Type horizon and locality. - Early Triassic, late Dienerian, from sample NAM101d, from about $6 \mathrm{~m}$ above the base of the Ceratite Marls (Ware et al. in press). Salt Range Pakistan, Nammal Nala.

Material. - See types.

Diagnosis. - Shell small, turbinid-hydrobiform; whorls strongly and evenly convex with periphery at about mid-whorl; sutures deep; first 2.5 whorls smooth (probably larval shell), later whorls with strengthened, strongly opisthocyrt growth-lines and spiral rows of minute pits; base evenly convex.

Description. - Shell high-spired, turbinid-hydrobiform, apical angle $35^{\circ}-40^{\circ}$; largest studied shell consist of more than 4 whorls, $0.9 \mathrm{~mm}$ high, $0.7 \mathrm{~mm}$ wide; embryonic whorl not sufficiently preserved to infer termination; initial whorl has diameter of $0.12 \mathrm{~mm}$ to $0.16 \mathrm{~mm}$; whorls strongly and evenly convex with periphery at about mid-whorl; sutures deep; first 2.5 whorls smooth, later whorls with strengthened, strongly opisthocyrt growthlines and at least 3 spiral rows of minute pits; base evenly convex, with a blunt edge at transition to whorl face in the most mature specimen studied.

Discussion. - Coelostylina hydrobiformis sp. nov. is the first nominate species of Induan age assigned to the genus Coelostylina. The first 2.5 smooth whorls probably represent a simple larval shell of the planktotrophic type whereas later whorls, probably representing the teleoconch, have strong growth-lines and tiny pits - both are absent in the first 2.5 whorls. The tiny pits arranged in several rows have not been reported from any other small smooth-shelled gastropod species from the Early Triassic except of $\mathrm{Coe}$ lostylina sp. as reported by Kaim et al. (2013) from a rock sample most likely derived from the Upper Ceratite Beds of Chideru, Pakistan (probably Mittiwali Member of Mianwali Formation, ?early Smithian, Early Triassic). The pre- sent shells are probably conspecific with Coelostylina sp. as reported by Kaim et al. (2013). However, Kaim et al. (2013) reported the presence of faint spiral lirae in their material (Kaim et al. 2013, fig. 7c) whereas this feature is absent in the present material.

Coelostylina hydrobiformis sp. nov. resembles several Triassic species which have been assigned either to the genus Coelostylina or the similar genus Omphaloptycha. However, many of these species are poorly known and features such as growth-line patterns as well as early ontogenetic shells have not been reported (some of them may be even nomina dubia). Moreover, spirally arranged pits are absent or unknown from nearly all of these species. Spirally arranged micro-pits have been reported for Coelostylina brevissima (Kittl, 1894) from the Ladinian Marmolada Limestone by Böhm (1895) and for Coelostylina solida (Koken, 1892) (in Wöhrmann \& Koken 1892) from the Carnian of the South Alps by Broili (1907). Both species are much broader and have less convex whorls than the present species. A new Coelostylina species from the Anisian of Romania has also spirally arranged pits (Nützel et al. 2018). However, it is much larger, has a deeper suture and the growth lines are straight instead of prosocyrt.

Coelostylina sp. from the Early Triassic of Primorye, Far East Russia (Kaim 2009) is more slender and has a more acute apex. Coelostylina costata Batten \& Stokes, 1986 from the Smithian Sinbad Limestone of Utah, USA has prominent axial ribs. Coelostylina virginensis Batten \& Stokes, 1986 from the same formation has much less convex whorls and a more acute shell shape. Coelostylina werfensis Wittenburg, 1908 from the Early Triassic Werfen Formation of the Alps is much more high-spired. Moreover, this species is based on steinkern material and thus hardly comparable. Pseudomurchisonia kokeni Wittenburg, 1908 from the same formation has a subsutural shoulder and sinus, both features are absent in Coelostylina hydrobiformis sp. nov. and Omphaloptycha schmidti Assmann, 1924 from the Rötdolomit of Poland (probably Spathian/Anisian) is similar but has less convex whorls and shallower sutures; its growth-line pattern is unknown. Omphaloptycha ahlburgi Assmann, 1924 and O. ecki Assmann, 1924 from the Anisian Muschelkalk of Poland are more slender and have straight growth lines. Omphaloptycha acuminata Assmann, 1924 from the Diploporenendolomit (Anisian, Muschelkalk) of Poland is more slender and its base is demarcated from the whorl face by a rounded edge; its growth-line pattern is unknown.

Few Late Palaeozoic species have been assigned to Coelostylina. The Late Permian Coelostylina gibsoni Brown, 1839 from England (see Hollingworth \& Barker 1991) is much more high-spired and slender and it has more convex whorls. A micro-punctation has not been 

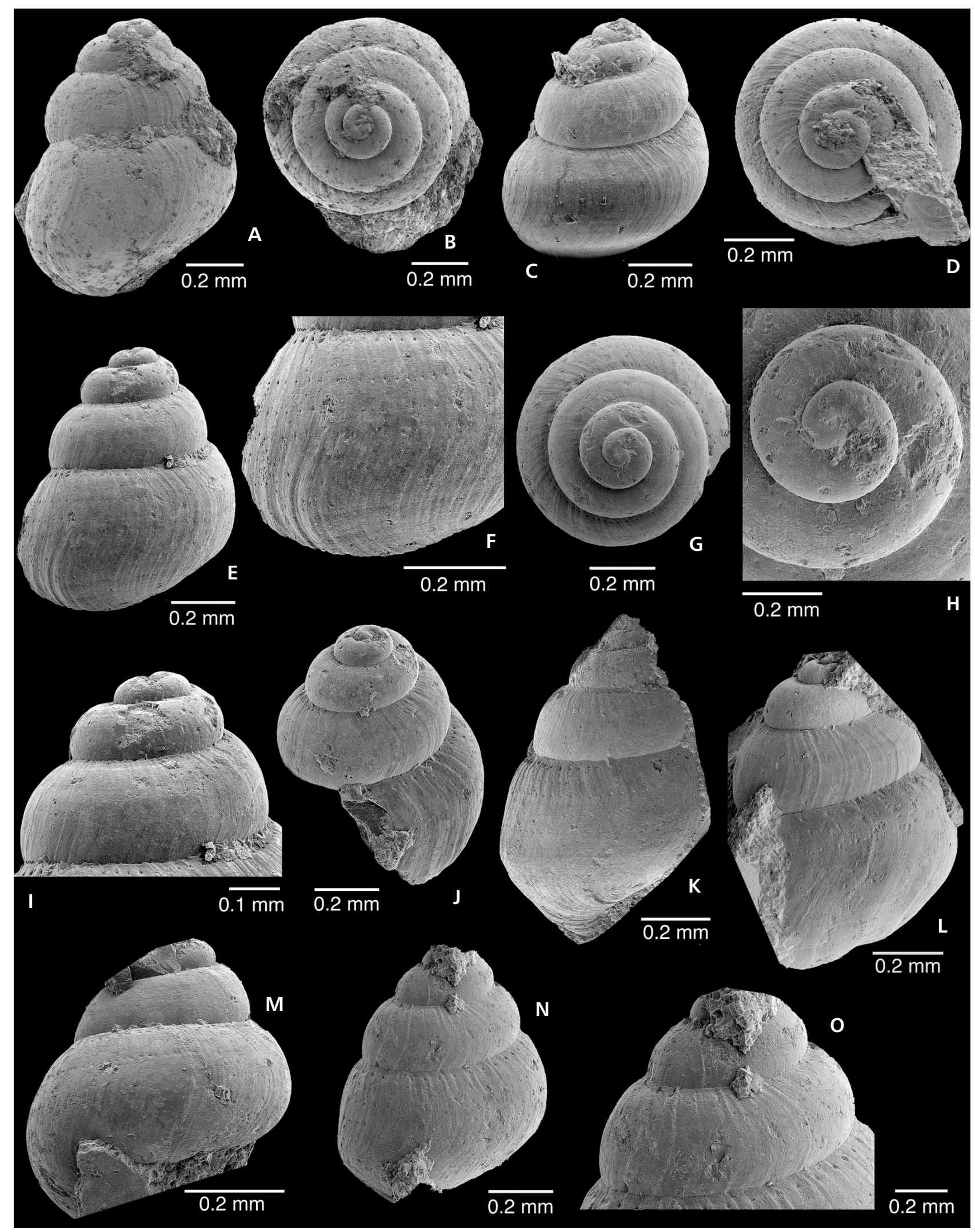

Figure 5. Coelostylina hydrobiformis sp. nov.; A, B - paratype, PIMUZ 32891; C, D - paratype, PIMUZ 32892; E-J - holotype, PIMUZ 32926 ; K - paratype, PIMUZ 32927; L - paratype, PIMUZ 32935; M - paratype, PIMUZ 32941; N, O - paratype, PIMUZ 32922. 
reported for it and its protoconch is unknown. Batten \& Stokes (1986) reported a single steinkern from the Smithian Sinbad Limestone (Utah, USA) as Coelostylina cf. angulifera (White, 1874). This specimen is much broader than Coelostylina hydrobiformis sp. nov. and has an angulated whorl profile. Originally Macorcheilus angulifera White, 1874 was reported from the Carboniferous of the USA and was later placed in the genus Girtyspira (Yochelson \& Saunders 1967).

Subclass Heterobranchia Burmeister, 1837

Grade "Lower Heterobranchia"

Superfamily Valvatoidea Gray, 1840

Family Hyalogyrinidae Warén \& Bouchet, 1993

(in Warén et al. 1993)

\section{Eographis Nützel \& Ware gen. nov.}

LSID. urn:1sid:zoobank.org:act:BBBF03A1-B262-4ED4 -9A17-9C380FC4E805

Type species. - Eographis microlineata sp. nov.

Etymology. - Early (Eos: Greek goddess of the dawn) precursor of the modern genus Graphis Jeffreys, 1867.

Diagnosis. - Valvatoid with a tofanellid larval shell i.e. with coaxial heterostrophy which is largely smooth except for axial wrinkles in its early portion; teleoconch acutely trochiform; teleoconch whorls evenly convex, ornamented with fine axial lirae and finer spiral lirae.

Description. - As for Eographis multilineata sp. nov., type species of Eographis which is monotypic at present.

Discussion. - Eographis is so far a monotypic genus and it may be asked whether the description of genera comprising only a single species is justified or desirable. A database of all Triassic gastropods (Nützel unpublished) indicates that almost $40 \%$ of all Triassic gastropod genera are monospecific. If a species has a character combination that does not fit an already described genus, the erection of a new monotypic genus is warranted and placement in a previously described genus could even be misleading. The high number of monospecific genera reflects the incompleteness of the fossil record. Monospecific genera are also the result of a lagerstätten-effect. For instance, many genera from the Late Triassic St. Cassian Formation are monospecific because of the exceptional good preservation which facilitates the observation of characters that are normally not preserved (such as protoconch characters). Without such a good preservation, the species would probably be placed in genera with convergent teleoconch morphology or poorly known type species.
Eographis differs from the modern genus Graphis Jeffreys, 1867 by having finer more densely spaced axial threads and in being broader. Recent Graphis species are very slender to needle-shaped and have much coarser axial ribs (e.g. Bandel 2005). Eographis gen. nov. resembles the genus Racheliella Nützel, 2018 (Mathildoidea), recently described from the from the Late Triassic St. Cassian Formation ( $\mathrm{N}$ Italy), by having a similar protoconch and by lacking strong ornament on the teleoconch. However, the ribs on the protoconch are much weaker in Eographis. Moreover, Racheliella differs by having a subsutural band with spiral lirae and parasigmoidal growth lines. In addition, Racheliella is more high-spired than Eographis gen. nov. Tofanella Bandel, 1995 and Cristalloella Bandel, 1995 (including the subgenus Wonwalica Schröder, 1995) from the Late Triassic St. Cassian Formation and the Jurassic of Central Europe are more slender, have carinated teleoconch whorls and a stronger and coarser teleoconch ornament. Camponaxis Bandel, 1995 from the Late Triassic St. Cassian Formation is more slender and has a stronger and coarser teleoconch ornament. The Jurassic genera Urlocella Gründel, 1998 (considered to represent a synonym of the pyramidellid genus Chrysallida by Kaim 2004) and Usedomella Gründel, 1998 are much more slender and lack the fine axial ornament of Eographis (see also Gründel \& Nützel 2013). The Jurassic genera Conusella Gründel, 1999 and Reinbergia Gründel, 2007 resemble Eographis in the relatively stout shape and in having a coaxial heterostrophic larval shell but differ in having an entirely smooth teleoconch. Schartiinae Nützel \& Kaim, 2014 (= Ampezzanildidae sensu Bandel 1995) have a coaxial heterostrophic larval shell with strong axial ribs on the larval shell which is not the case in Eographis. Trachoecus Kittl, 1894 (Late Triassic St. Cassian Formation has an ornament of few but very strong axial ribs crossed by few but distinct spiral cords which is not the case in Eographis. Carboninia Bandel, 1996 from the Late Triassic St. Cassian Formation resembles Eographis in shape and in having coaxial heterostrophy but differs in having a smooth shell. The modern deep sea genera Hyalogyra Marshall, 1988 and Hyalogyrina Marshall, 1988 (Valvatoidea, Hyalogyrinidae) are similar but are usually more low-spired (except for Hyalogyrina risoella Warén \& Bouchet, 2009 which is as high-spired as Eographis), have a smooth teleoconch and lack axial wrinkles on the early protoconch (e.g. Marshall 1988, Warén \& Bouchet 1993). The Devonian Palaeocarboninia Bandel \& Heidelberger, 2002 (Cornirostridae) resembles Eographis in shape and in having coaxial heterostrophy. However, Palaeocarboninia has a smooth shell. Moreover, due to preservation, the transition from protoconch to teleoconch cannot be seen. The Carboniferous genus Heteroaclisina Bandel, 2002b (Donaldinidae) also resembles Eographis in shape and in having coaxial heterostrophy. However, 
Heteroaclisina has a dominant spiral ornament on the teleoconch.

\section{Eographis microlineata Nützel \& Ware sp. nov.} Figure 6

LSID. urn:lsid:zoobank.org:act:0FB18883-FD88-4CF6-8 158-057E0EF1A3AD

Types. - Holotype (PIMUZ 32911) and 10 paratypes (PIMUZ 32881, 32916, 32919, 32921, 32923, 32928, 32929, 32933, 32934, 32936, 32940, 32942, 32943).

Type horizon and locality. - Early Triassic, late Dienerian, from sample NAM101d, from about $6 \mathrm{~m}$ above the base of the Ceratite Marls (Ware et al. in press). Salt Range Pakistan, Nammal Nala.

Material. - See types.

Etymology. - For the fine teleoconch ornament of axial and spiral threads.

Diagnosis. - As for genus which is monotypic at present.

Description. - Teleoconch trochiform; holotype comprise $c a$. 3.5 whorl, $10.3 \mathrm{~mm}$ high, $0.9 \mathrm{~mm}$ wide; teleoconch whorls evenly convex, embracing slightly below periphery, ornamented with fine but distinct axial lirae and finer spiral lirae; axial lirae almost straight, orthocline, only slightly sinuous, distinctly curving forward at adapical suture and slightly prososcyrt on whorl face; base evenly convex, not demarcated from whorl face; protoconch flatly lying on apex, coaxial heterostrophic with immersed initial part; protoconch consisting of 1.4-1.5 rapidly increasing whorls, $0.33-0.37 \mathrm{~mm}$ in diameter; first part of visible protoconch with axial (radial) wrinkles, later largely smooth; transition to teleoconch abrupt with a ledge.

Infraclass Euthyneura

Superfamily Acteonoidea d'Orbigny, 1843

Family Tubiferidae Cossmann, 1895

\section{Genus Sinuarbullina Gründel, 1997}

Type species. - Sinuarbullina ansorgi Gründel, 1997, Jurassic, Bathonian, NE Germany, NW Poland.

\section{Sinuarbullina sp.}

Figure 7

Material. - One specimen (PIMUZ 32883) from sample NAM101d, from Nammal Nala, about $6 \mathrm{~m}$ above the base of the Ceratite Marls (Ware et al. in press), Salt Range Pakistan, Early Triassic.

Description. - Shell slender, exposing about 4 whorls, ca. $0.9 \mathrm{~mm}$ high, $0.5 \mathrm{~mm}$ wide; spire gradate with distinct subsutural ramp; ramp almost horizontal to slightly inclined; whorl face concave below ramp and evenly convex at periphery; growth lines distinct, strongly sinuous, opisthocyrt below ramp, prosocyrt at periphery.

Remarks. - Although the protoconch is not preserved in the present specimen, the generic identity is beyond doubt because of the typical and characteristic teleoconch morphology. Shells like this were previously placed in the genus Cylindrobullina (see Gründel \& Nützel 2012).

\section{Discussion and conclusions}

The studied sample derives from a limestone bed of Dienerian age with abundant ammonoids. The matrix between the ammonoids yielded thousands of tiny gastropods $(<2 \mathrm{~mm})$ representing five species. The great majority $(>90 \%)$ are isolated larval shells and early juveniles of the soleniscid caenogastropod Strobeus pakistanensis. The other taxa are isolated larval shells of a trachyspirid (Neritimorpha) taxon, the small sized caenogastropod species Coelostylina hydrobiformis sp. nov. as well as the heterobranchs Eographis microlineata gen. nov., sp. nov. and Sinuarbullina sp.

The studied gastropod assemblage has a low diversity comprising only 5 species. It shows a pronounced faunal homogeneity with a strong dominance of Strobeus pakistanensis. The high number of isolated larval and early juvenile shells indicates that this assemblage did not form under normal marine living conditions before transport by storm but that at least one environmental parameter hindered larger growth of the juveniles or a successful metamorphosis of the larvae. Poor living conditions on the sea floor - maybe caused by oxygen deficiency - are thus reflected by larval fall (no metamorphosis possible) or high mortality (high abundance of early juveniles). However, the small-sized species could have been adapted to low oxygen concentrations. The small size does not result from post mortem size-sorting because larger ammonoids and shell fragments are present in the studied sample which represents a poorly sorted tempestite. The fact that ammonoids are also abundant while fossil remains of larger benthic animals seem to be absent also argue for poor living conditions on the sea floor and that the main source for the fossils was the plankton and the nekton. A similar cephalopod-microgastropod association though without storm-generated transport - was reported from the Early Carboniferous Ruddle Shale in Arkansas, USA (Nützel \& Mapes 2001, Mapes \& Nützel 2009). In 
this case primarily pyritized cephalopods and tiny gastropods $(<2 \mathrm{~mm})$ occur abundantly in black shale whereas larger benthic animal are almost entirely absent. This has been interpreted as a mixture of larval fall and nektonic organisms and the almost entire lack of benthos as result of bottom water oxygen deficiency. The present sample can be interpreted as an analogue facies in the calcareous realm. However, the presence of many clearly post-larval, mostly juvenile gastropods suggests that oxygen concentration were sufficient to permit at least temporarily a short live span on the bottom. The tiny gastropod shells reported from the Smithian of north-eastern Vietnam by Kaim et al. (2014) have also been interpreted as isolated larval conchs or early juveniles of taxa having mostly planktotrophic larval development. This assumption was based on the small size of the specimens (smaller than $1 \mathrm{~mm}$ ) and the fact that the initial whorl is present in most specimens showing that the apical portions of gastropods are present (as in the case of the gastropods studied here). The small size of these gastropods is no evidence for the Liliput Effect which proposes a generally small adult size after the extinction event (see e.g. Fraiser \& Bottjer 2004; Fraiser et al. 2005, 2011; Brayard et al. 2010, 2011, 2015 for discussion).

A hallmark of the present fossil assemblage is the excellent preservation of the gastropods including protoconchs and micro-ornaments. Good protoconch preservation in Early Triassic gastropods has only been reported from the Smithian Sinbad Limestone of Utah, USA (Batten \& Stokes 1986, Nützel 2005, Nützel \& Schulbert 2005), the Chinese Dayie Formation (Hua Zhang et al. 2003), the Early Triassic of Far East Russia (Kaim 2009), the Olenekian of Vietnam (Kaim et al. 2014) and from a silicified Griesbachian fauna from Spitsbergen (Foster et al. 2017). The total number of described Early Triassic gastropod species is very low and most species are based on poorly preserved material lacking protoconch preservation. However, in many gastropod species the knowledge of the protoconch is crucial for a correct classification and therefore also for the analyses of evolutionary lineages at critical intervals such as the end-Permian mass extinction event and subsequent recovery. Therefore, the present assemblage, being the first record of Dienerian gastropods with well-preserved protoconchs, adds important information about gastropod evolution after the end-Permian mass extinction event.

The characteristic isolated trachyspirid larval shells in the present fauna show that this Palaeozoic group survived the mass extinction and its presence in the Dienerian bridges the Lazarus-gap between the Permian (Nützel et al. 2007, Pan \& Erwin 2002) and the Late Triassic (Bandel 2007, as Naticopsidae). Neritimorphs with this type of axially ribbed larval shells have not been reported from post-Triassic strata so that Trachyspiridae probably became extinct in the Late Triassic, possibly during the end-Triassic mass extinction event.
The highly abundant larval and juvenile shells of Strobeus pakistanensis belong to the 'subulitoid' family Soleniscidae which was diverse and widespread in the Late Palaeozoic. The survival of this group into the early Triassic has repeatedly been shown at a global scale (Batten \& Stokes 1986, Nützel 2005, Wheeley \& Twitchett 2005, Kaim 2009, Kaim et al. 2013) but its relationships to younger smooth-shelled caenogastropods remain unclear.

The caenogastropod genus Coelostylina, represented by the new species $C$. hydrobiformis, has previously been reported from the Permian and the Early Triassic with a few species (see Kaim et al. 2013 for discussion). According to the current state of knowledge this genus ranges from the Middle Permian to the Jurassic. In the Early Triassic, the present specimens of Coelostylina are the best preserved ever recorded. They have orthostrophic initial whorls probably representing a smooth larval shell. This information is crucial because small high-spired shells have evolved in several gastropod groups. For instance Heterobranchia and Caenogastropoda commonly have homoplastic teleoconch morphologies but based on the present well-preserved material it can be excluded that C. hydrobiformis is a member of the Heterobranchia.

The presence of the new genus Eographis is an important feature of the studied fauna. As discussed above, its placement in Hyalogyrinidae seems to be the best solution although "lower heterobranchs", both modern and fossil are an unresolved group with a spotty fossil record and a lack of molecular and anatomical studies in many living taxa. The possibility that Eographis belongs to the heterobranch Pyramidelloidea lineage (e.g. it resembles modern genera such as Chrysallida to some degree) cannot be ruled out. However, since Pyramidellidae of this relation commonly have a tooth in the aperture and differ widely in teleoconch ornament this relationship is seen as unlikely. Moreover pyramidellids lack axial wrinkles on the protoconch. It is unclear whether Eographis could also belong to Cornirostridae (also marine Valvatoidea) based on its resemblance to the Late Triassic Carboninia. However, shell shape in this group is usually depressed trochiform and distinctly umbilicated.

Eographis has coaxial heterostrophy which is also present in the mathildoid family Tofanellidae. However, the teleoconch of Eographis differs considerably from most Mathildoidea including tofanellids in shell shape and ornamentation. The present material of Eographis represents the first Early Triassic example of a protoconch with coaxial heterostrophy. There are a few Palaeozoic (Devonian, Carboniferous) examples for gastropods with coaxial heterostrophy (Bandel 2002b; Bandel \& Heidelberger 2002) which could actually also belong to Hyalogyrinidae or Cornirostridae. These Palaeozoic genera, Heteroaclisina and Palaeocarboninia, may be closely related to Eographis. This group of ancient lower heterobranchs may 


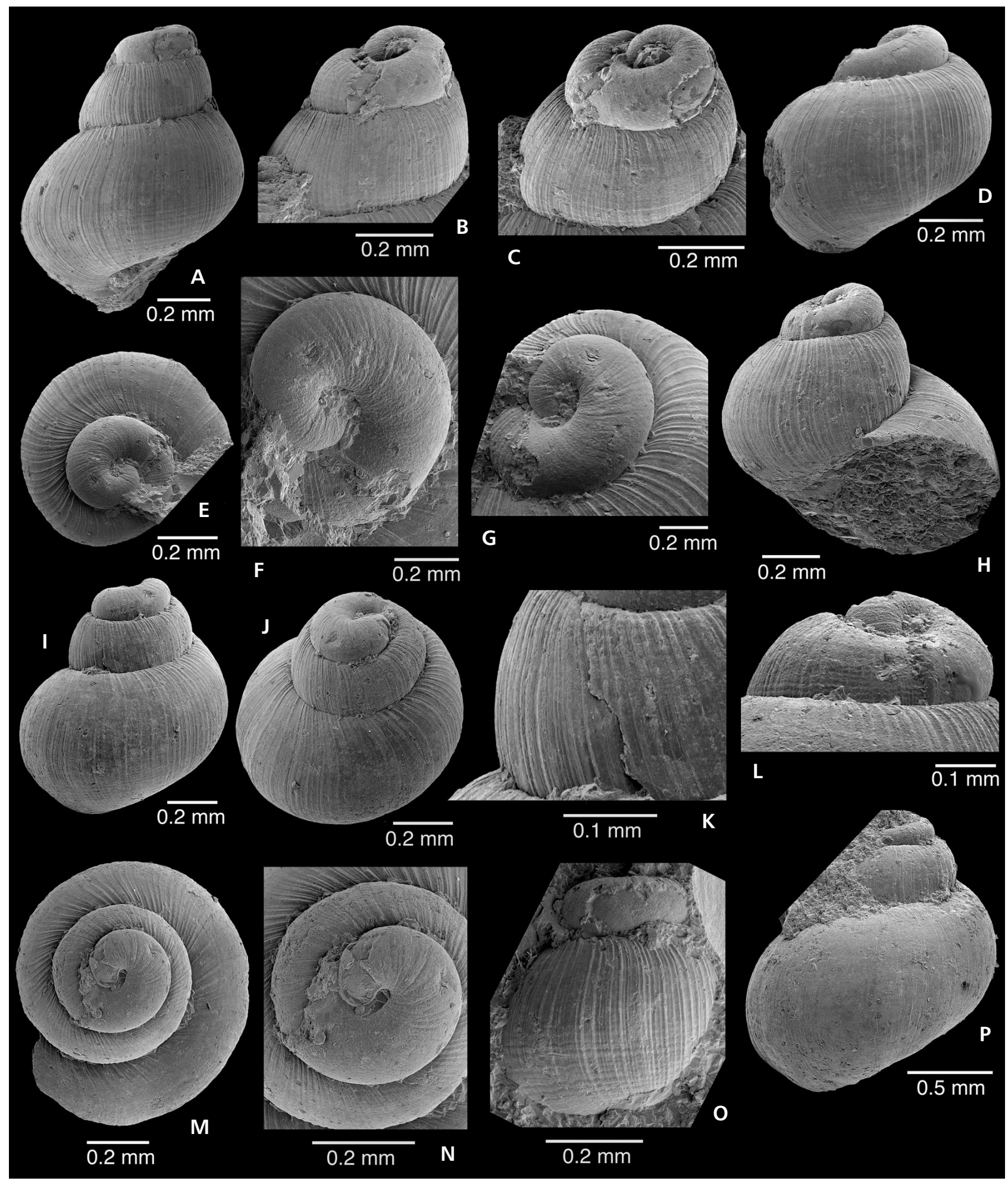

Figure 6. Eographis microlineata sp. nov.; A-C - holotype, PIMUZ 32911; D-G - paratype, PIMUZ 32916; H, I - paratype, PIMUZ 32919 ; J-N - paratype, PIMUZ 32942; O - paratype, PIMUZ 32923; P - paratype, PIMUZ 32943.

include evolutionary lineages that gave rise to modern groups such as Mathildoidea. The high age of this group resembling living ectobranchs supports statements that living Ectobranchia (Hyalogyrinidae, Valvatidae, Cornirostridae and Xylodisculidae) represent the first extant offshoot of the Heterobranchia (Haszprunar et al. 


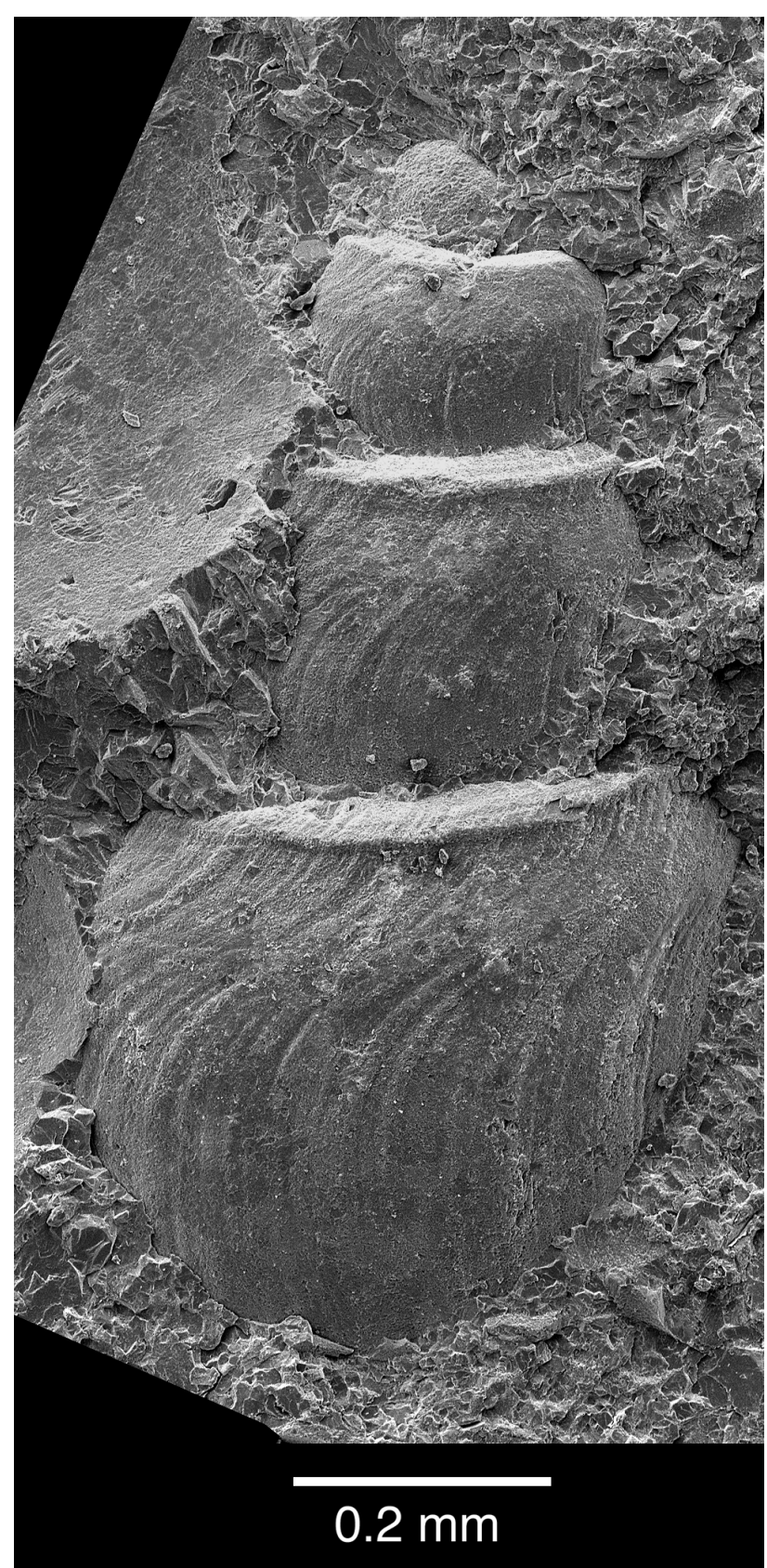

Figure 7. Sinuarbullina sp., PIMUZ 32883.

2011). The earliest occurrence of the diverse superfamily Mathildoidea as evidenced by the knowledge of the protoconch are from the Late Triassic. The protoconch of Promathildia spirocostata Batten \& Stokes, 1986 from the Smithian Sinbad Limestone is unknown and its teleoconchs is not particularly typical of Promathildia (Nützel 2005). Mathildoidea are richly diversified throughout the Mesozoic and are still diverse today (Bandel 1995, Bieler 1995, Gründel \& Nützel 2013).

Sinuarbullina sp. in the present collection is a typical representative of this genus. The oldest known species is
Sinuarbullina yangouensis (Pan, Erwin, Nützel \& Xiang-shui, 2003) from the Early Triassic of China (Pan et al. 2003) and the Griesbachian of Spitsbergen (Foster et al. 2017). Sinuarbullina convexa (Batten \& Stokes, 1986) from the Smithian Sinbad Limestone of Utah is also similar (see also Nützel 2005, Nützel \& Schulbert 2005, Gründel $\&$ Nützel 2012). So far, no members of Sinuarbullina or related heterostrophic genera of the tubiferid/cylindrobullinid-group have been reported from the Palaeozoic so that the entire group seems to have originated in the earliest Triassic, thus providing additional evidence for the Early Triassic heterobranch turnover (Nützel 2005, Gründel \& Nützel 2012).

Of the five genera present in the studied Dienerian assemblage, three are holdovers from the Palaeozoic (Strobeus, Coelostylina, trachyspirid) and two originate in the Early Triassic (Eographis, Sinuarbullina). The status of Coelostylina is in this respect unsafe because its Permian members are not sufficiently known. Eographis and Sinuarbullina represent the earliest occurrences of important heterobranch groups, indicating a considerable turnover within Heterobranchia during the aftermath of the end-Permian mass extinction event. Most of the present gastropods had planktotrophic larval development providing further evidence against the hypothesis that the end-Permian mass extinction event selected against larval planktotrophy (Valentine 1986, see Nützel 2014 for further discussion).

\section{Acknowledgements}

We thank Andrzej Kaim (Warszawa), Winston Ponder (Sydney) and Anders Warén (Stockholm) for helpful discussions about the systematic placement of the new genus Eographis. Stefano Monari (Padova) and Peter Wagner (Lincoln) are acknowledged for their helpful reviews. AN acknowledges support by the Deutsche Forschungsgemeinschaft (Grant NU 96/6-1, 6-2). The study of the Early Triassic record in the Salt Range was supported by the Swiss National Science Foundation (project SNF 135446 to HB).

\section{Data archiving statement}

This published work and the nomenclatural acts it contains have been registered in ZooBank:

http://zoobank.org/urn:lsid:zoobank.org:pub:D4BA361F -DOFF-476F-8425-B887D8616B0C

\section{References}

Assmann, P. 1924. Die Gastropoden der oberschlesischen Trias. Jahrbuch der Preussischen Geologischen Landesanstalt 44, 1-50. 
BANDEL, K. 1995. Mathildoidea (Heterostropha, Gastropoda) from the Upper Triassic St. Cassian Formation. Scripta Geologica 111, 1-83.

BANDEL, K. 1996. Some heterostrophic gastropods from Triassic St. Cassian Formation with a discussion on the classification of the Allogastropoda. Paläontologische Zeitschrift 70, 325-365. DOI 10.1007/BF02988078

BANDEL, K. 2002a. Reevaluation and classification of Carboniferous and Permian Gastropoda belonging to the Caenogastropoda and their relation. Mitteilungen aus dem Geologisch-Paläontologischen Institut der Universität Hamburg 86, 81-188.

BANDEL, K. 2002b. About Heterostropha (Gastropoda) from the Carboniferous and Permian. Mitteilungen aus dem Geologisch-Paläontologischen Institut der Universität Hamburg 86, 45-80.

BANDEL, K. 2005. Living fossils among tiny Allogastropoda with high and slender shell from the reef environment of the Gulf of Aquba with remarks on fossil and recent relatives. Mitteilungen aus dem Geologisch-Paläontologischen Instituts der Universität Hamburg 89, 1-24.

BANDEL, K. 2007. Description and classification of Late Triassic Neritimorpha (Gastropoda, Mollusca) from the St Cassian Formation, Italian Alps. Bulletin of Geosciences 83, 215-274. DOI 10.3140/bull.geosci.2007.03.215

Bandel, K. \& Heidelberger, D. 2002. A Devonian member of the subclass Heterostropha (Gastropoda) with valvatoid shell shape. Neues Jahrbuch für Geologie und Paläontologie, Monatshefte 2002/9, 533-550.

BAtTen, R.L. \& Stokes, W.M. 1986. Early Triassic gastropods from Sinbad Member of the Moenkopi Formation, San Rafael Swell, Utah. American Museum Novitates 2864, 1-33.

BIELER, R. 1995. Mathildidae from New Caledonia and the Loyalti Islands (Gastropoda: Heterobranchia). Mémoires Musee national Histoire naturelle 167, 595-641.

Böнм, J. 1895. Die Gastropoden des Marmolatakalkes. Palaeontographica 42, 211-308.

Bouchet, P., Rocroi, R.P., Hausdorf, B., Kaim, A., Kano, Y., NÜtZel, A., PARkhaev, P., SchröDl, M. \& Strong, E.E. 2017. Revised classification, nomenclator and typification of gastropod and monoplacophoran families. Malacologia 61, 1-526. DOI 10.4002/040.061.0201

Brayard, A., Bucher, H., Escarguel, G., Fluteau, F., Bourquin, S. \& Galfetti, T. 2006. The Early Triassic ammonoid recovery: Paleoclimatic significance of diversity gradients. Palaeogeography, Palaeoclimatology, Palaeoecology 239, 374-395. DOI 10.1016/j.palaeo.2006.02.003

Brayard, A., Meier, M., Escarguel, G., Fara, E., Nützel, A., Olivier, N., Bylund, K.G., Jenks, J.F., Stephen, D.A., Hautmann, M., Vennin, E. \& Bucher, H. 2015. Early Triassic Gulliver gastropods: spatio-temporal distribution and significance for the biotic recovery after the end-Permian mass extinction. Earth-Science Reviews 164, 31-64. DOI 10.1016/j.earscirev.2015.03.005

Brayard, A., Nützel, A., Stephen, D.A., Bylund, K.G., Jenks, J. \& BuChER, H. 2010. Gastropod evidence against the Early Tri- assic Lilliput effect. Geology 38, 147-150.

DOI 10.1130/G30553.1

Brayard, A., Nützel, A., Kaim, A., Escarguel, G., Hautmann, M., Stephen, D.A., Bylund, K.G., Jenks, J., \& Bucher, H. 2011. Gastropod evidence against the Early Triassic Lilliput effect: Reply. Geology 39, 147-150. DOI 10.1130/G31765Y.1

Broili, F. 1907. Die Fauna der Pachycardientuffe der Seiser Alp. Scaphopoden und Gastropoden. Palaeontographica 54, 69-138.

Brown, T. 1839. Description of the fossil shells found at Newton, Manchester. Transactions of the Geological Society of Manchester 1, 63-66.

Brühwiler, T., Bucher, H., Brayard, A. \& Goudemand, N. 2010. High-resolution biochronology and diversity dynamics of the Early Triassic ammonoid recovery: the Smithian faunas of the Northern Indian Margin. Palaeogeography, Palaeoclimatology, Palaeoecology 297, 491-501.

DOI 10.1016/j.palaeo.2010.09.001

Brühwiler, T., Bucher, H., Roohi, G., Yaseen, A., \& Rehman, K. 2011. A new early Smithian ammonoid fauna from the Salt Range (Pakistan). Swiss Journal of Palaeontology 130, 187-201. DOI 10.1007/s13358-011-0018-3

Brühwiler, T., Bucher, H., Ware, D., Hermann, E., Hochuli, P.A., Roohi, G., Rehman, K. \& Yaseen, A. 2012. Smithian (Early Triassic) ammonoids from the Salt Range, Pakistan. Special Papers in Palaeontology 88, 1-114.

Burmeister, H. 1837, Handbuch der Naturgeschichte, vol. 2, Zoologie. i-xii, 369-858, Enslin, Berlin.

Cossmann, M. 1895. Essais de Paléoconchologie Comparée. Première Livraison. 161 pp. M. Cossmann, Comptoir Géologique, Paris.

Cossmann, M. 1909. Essais de Paléoconchologie Comparée. Huitième Livraison. 248 pp. M. Cossmann, F. R. de Rudeval, Paris.

Cox, L.R. 1960. Thoughts on the classification of the Gastropoda. Proceedings of the Malacological Society of London 33, 239-261.

Cuvier, G. 1797. Tableau élémentaire de l'histoire naturelle des animaux. 710 pp. Baudoin, Paris.

Foster, W.J., Danise, S. \& Twitchett, R.J. 2017. A silicified Early Triassic marine assemblage from Svalbard. Journal of Systematic Palaeontology 15, 851-877. DOI 10.1080/14772019.2016.1245680

Fraiser, M.L. \& BottJer, D.J. 2004. The non-actualistic Early Triassic gastropod fauna. Palaios 19, 259-275. DOI 10.1669/0883-1351(2004)019<0259:TNETGF>2.0.CO;2

Fraiser, M.L., Twitchett, R.J., Frederickson, J.A., Metcalfe, B. \& BotTJER, D.J. 2011. Gastropod evidence against the Early Triassic Lilliput effect: Comment. Geology 39, e232. DOI 10.1130/G31614C.1

Fraiser, M.L., Twitchett, R.J. \& BottJer, D.J. 2005. Unique microgastropod biofacies in the Early Triassic: Indicator of long-term biotic stress and the pattern of biotic recovery after the end-Permian mass extinction. Comptes Rendus Palevol 4, 475-484. DOI 10.1016/j.crpv.2005.04.006 
GiRTY, G.H. 1927. Descriptions of new species of Carboniferous and Triassic fossils, 434-446. In Mansfield, G.R. (ed.). Geography geology and mineral resources of part of southeastern Idaho With descriptions of Carboniferous and Triassic fossils. US Geological Survey Professional Paper 152, $1-453$.

GRAY, J.E. 1840. A manual of the land and freshwater shells of the British Islands by W. Turton. ix +324 pp., 12 pls. Longman, Rees, Orme, Brown and Green, London.

GRÜNDEL, J. 1997. Heterostropha (Gastropoda) aus dem Dogger Norddeutschlands und Nordpolens. III. Opisthobranchia. Berliner geowissenschaftliche Abhandlungen, Reihe E 25, 177-223.

GRÜNDEL, J. 1998. Heterostropha (Gastropoda) aus dem Dogger Norddeutschlands und Nordpolens. II. Weitere Allogastropoda. Freiberger Forschungshefte C474, 1-37.

GRÜNDEL, J. 1999. Gastropoden aus dem höheren Lias von Grimmen (Vorpommern) (Deutschland). Archiv für Geschiebekunde 2, 629-672.

GRÜNDEL, J. 2007. Gastropoden des Pliensbachiums (unterer Jura) aus Bohrungen der Usedom-Senke (Nordostdeutschland). Zitteliana A 47, 69-103.

GRÜNDEL, J. \& NÜTZEL, A. 2012. On the early evolution (Late Triassic to Late Jurassic) of the Architectibranchia (Gastropoda: Heterobranchia) with a provisional classification. Neues Jahrbuch für Geologie und Paläontologie, Abhandlungen 264, 31-59. DOI 10.1127/0077-7749/2012/0230

GRÜNDEL, J. \& NÜTZEL, A. 2013. Evolution and classification of Mesozoic mathildoid gastropods. Acta Palaeontologica Polonica 58, 859-882.

GuEx, J. 1978. Le Trias inférieur des Salt Ranges (Pakistan): Problémes biochronologiques. Eclogae Geologicae Helvetiae 71, 105-141.

HALL, J. 1856. Description of new species of fossils from the Carboniferous limestones of Indiana and Illinois. Transactions of the Albany Institute 4, 1-36.

Haszprunar, G., Speimann, E., Hawe, A. \& Mess, M. 2011. Interactive $3 \mathrm{D}$ anatomy and affinities of the Hyalogyrinidae, basal Heterobranchia (Gastropoda) with a rhipidoglossate radula. Organisms, Diversity and Evolution 11, 201-236.

DOI 10.1007/s13127-011-0048-0

Hautmann, M., Smith, A.B., McGowan, A.J., \& Bucher, H. 2013. Bivalves from the Olenekian (Early Triassic) of southwestern Utah: Systematics and evolutionary significance. Journal of Systematic Palaeontology 11(3), 263-293. DOI 10.1080/14772019.2011.637516

Hermann, E., Hochuli, P.A., Bucher, H., Brühwiler, T., Hautmann, M., Ware, D. \& Roohi, G. 2011a. Terrestrial ecosystems on North Gondwana following the end-Permian mass extinction. Gondwana Research 20, 630-637. DOI 10.1016/j.gr.2011.01.008

Hermann, E., Hochuli, P.A., Méhay, S., Bucher, H., Brühwiler, T., Ware, D., Hautmann, M., Roohi, G., uR-Rehman, K. \& YASEEN, A. 2011b. Organic matter and palaeoenvironmental signals during the Early Triassic biotic recovery: The Salt Range and Surghar Range records. Sedi- mentary Geology 234, 19-41.

DOI 10.1016/j.sedgeo.2010.11.003

Hermann, E., Hochuli, P.A., Bucher, H., Brühwiler, T., Hautmann, M., Ware, D., Weissert, H., Roohi, G., Yaseen, A. \& UR-Rehman, K. 2012a. Climatic oscillations at the onset of the Mesozoic inferred from palynological records from the North Indian Margin. Journal of the Geological Society, London 169, 227-237. DOI 10.1144/0016-76492010-130

Hermann, E., Hochuli, P.A., Bucher, H. \& Roohi, G. 2012 b. Uppermost Permian to Middle Triassic palynology of the Salt Range and Surghar Range, Pakistan. Review of Palaeobotany and Palynology 169, 61-95.

DOI 10.1016/j.revpalbo.2011.10.004

Hollingworth, N.T.J. \& Barker, M.J. 1991. Gastropods from the Upper Permian Zechstein (Cycle 1) reef of north-east England. Proceedings of the Yorkshire Geological Society 48, 347-365. DOI 10.1144/pygs.48.4.347

Hua Zhang, P., \& ERwin, D.H. 2002. Gastropods from the Permian of Guangxi and Yunnan provinces, South China. Journal of Paleontology. The Paleontological Society Memoir 76(56), $1-49$.

Hua Zhang, P., Erwin, D.H., NütZel, A. \& Xiang Shui, Z. 2003. Jiangxispira, a new gastropod genus from the Early Triassic of China with Remarks on the phylogeny of the Heterostropha at the Permian/Triassic Boundary. Journal of Paleontology 77, $44-49$.

DOI 10.1666/0022-3360(2003)077<0044:JANGGF>2.0.CO;2

JEFFREYS, J.G. 1862-1869. British Conchology. Vol. 1: CXIV + 341 pp. [1862]. Vol. 2: 479 pp. [1864] Il frontrespizio reca la data $1863 \mathrm{ma}$ in effetti pubblicato nel 1864. Vol. 3: 394 pp. [1865]. Vol. 4: 487 pp. [1867]. Vol. 5: 259 pp. [1869]. van Voorst, London.

KaIM, A. 2004. The evolution of conch ontogeny in Mesozoic open sea gastropods. Palaeontologia Polonica 62, 1-182.

KaIM, A. 2009. Gastropods, 141-156. In SHIGETA, Y., ZaKharov, Y.D., Maeda, H. \& Popov, A.M. (eds) The Lower Triassic System in the Abrek Bay area, South Primorye, Russia. National Museum of Nature and Science Monographs 38.

Kaim, A., Nützel, A., Hautmann, M. \& Bucher, H. 2013. Early Triassic gastropods from Salt Range, Pakistan. Bulletin of Geosciences 88, 505-516. DOI 10.3140/bull.geosci.1395

KaIM, A., NÜTZEL, A. \& MAEKAWA, T. 2014. Smithian gastropod assemblages of the Bac Thuy Formation. In SHIGETA, Y., Komatsu, T., Maekawa, T. \& Dang, H.T. (eds) Olenekian (Early Triassic) stratigraphy and fossil assemblages in northeastern Vietnam. National Museum of Nature and Science Monographs 45, 63-64.

KitTL, E. 1894. Die Gastropoden der Schichten von St. Cassian der südalpinen Trias. 3. Theil. Annalen des kaiserlichköniglichen Naturhistorischen Hofmuseums 9, 143-275.

KnIGHT, J.B. 1931. The gastropods of the St. Louis, Missouri, Pennsylvanian outlier: the Subulitidae. Journal of Paleontology 5, 177-229. DOI 10.1130/SPE32-p1

KNIGHT, J.B. 1941. Paleozoic gastropod genotypes. Geological Society of America Special Papers 32, 1-510.

KoKen, E. 1896. Die Gastropoden der Trias um Hallstatt. 
Jahrbuch der kaiserlich-königlichen Geologischen Reichsanstalt 46, 37-126.

KonINCK, L.G. DE 1881. Faune du calcaire carbonifère de la Belgique, 3e partie, Gastéropodes. Musée Royale d'Historie Naturelle Belgique Annales, Série Paléontoloque 6, 1-170.

Kues, B.S. \& Batten, R.L. 2001. Middle Pennsylvanian gastropods from the Flechado Formation, north-central New Mexico. Journal of Paleontology 75, Supplement to No. 1, $1-95$.

Kues, B.S., Batten, R.L., ERwin, D.H. \& Hua Zhang, P. 2004. A Late Permian Chinese gastropod species, possibly larval, in the Middle Pennsylvanian of New Mexico. Journal of Paleontology $78,420-423$.

DOI 10.1666/0022-3360(2004)078<0420:ALPCGS >2.0.CO;2

Kummel, B. 1966. The Lower Triassic Formations of the Salt Range and Trans-Indus Ranges, West Pakistan. Bulletin of the Museum of Comparative Zoology 134, 361-429.

Kummel, B. \& Teichert, C. 1970. Stratigraphy and paleontology of the Permian-Triassic boundary beds, Salt Range and Trans-Indus Ranges, West Pakistan. Stratigraphic Boundary Problems: Permian and Triassic of West Pakistan. University of Kansas Department of Geology Special Publication 4, $1-110$.

Mapes, R.H. \& NütZel, A. 2009. Where did Upper Paleozoic cephalopods lay their eggs? - Evidence from cephalopod embryos and gastropod and pelecypod veliger larvae. Lethaia 42, 341-356. DOI 10.1111/j.1502-3931.2008.00141.x

Marshall, B.A. 1988. Skeneidae, Virtinellidae and Orbistellidae (Mollusca: Gastropoda) associated with biogenic substrata from bathyal depths off New Zealand and New South Wales. Journal of Natural History 22, 949-1004. DOI 10.1080/00222938800770631

Murata, M. 1981. Permian and Triassic Gastropoda from Guryul Ravine. Palaeontologia Indica 46, 125-133.

MÜNSTER, G.G. ZU 1841. Beiträge zur Geognosie und Petrefacten-Kunde des Südöstlichen Tirol's vorzüglich der Schichten von St. Cassian. 152 pp. Buchner'schen Buchhandlung, Bayreuth.

NütZel, A. 2005. Recovery of gastropods in the Early Triassic. Comptes Rendus Palevol 4, 501-515. DOI 10.1016/j.crpv.2005.02.007

NÜTZEL, A. 2014. Larval ecology and morphology in fossil gastropods. Palaeontology 57, 479-503.

DOI 10.1111/pala.12104

NüTZEL, A. 2018. Racheliella, a new mathildoid gastropod genus (Gastropoda, lower Heterobranchia) from the Late Triassic St. Cassian Formation (N Italy). Neues Jahrbuch für Geologie und Paläontologie Abhandlungen 287(2), 207-211. DOI 10.1127/njgpa/2018/0713

NütZel, A., FrÝdA, J., Yancey, T.E. \& Anderson, J.R. 2007. Larval shells of Late Palaeozoic naticopsid gastropods (Neritopsoidea: Neritimorpha) with a discussion of the early neritimorph evolution. Paläontologische Zeitschrift 81, 213-228. DOI 10.1007/BF02990173

NüTZEL, A. \& KaIM, A. 2014. Diversity, palaeoecology and sys- tematics of a marine fossil assemblage from the Late Triassic Cassian Formation at Settsass Scharte, N Italy. Paläontologische Zeitschrift 88, 405-431.

DOI 10.1007/s12542-013-0205-1

NüTZEL, A. \& MAPES, R.H. 2001. Larval and juvenile gastropods from a Carboniferous black shale: palaeoecology and implications for the evolution of the Gastropoda. Lethaia 34, 143-162. DOI 10.1080/00241160152418447

Nützel, A. \& Hua Zhang, P. 2005. Late Paleozoic evolution of the Caenogastropoda: larval shell morphology and implications for the Permian/Triassic mass extinction event. Journal of Paleontology 79, 1175-1188.

DOI 10.1666/0022-3360(2005)079[1175:LPEOTC]2.0.CO;2

NüTzel, A. \& SChUlberT, C. 2005. Facies of two important Early Triassic gastropod lagerstätten: implications for diversity patterns in the aftermath of the end-Permian mass extinction. $F a$ cies 51, 480-500. DOI 10.1007/s10347-005-0074-5

Nützel, A., Kaim, A. \& Grădinaru, E. 2018. Middle Triassic (Anisian, Bithynian) gastropods from North Dobrogea (Romania) and their meaning for the recovery from the end-Permian mass extinction event. Papers in Palaeontology. DOI 10.1002/spp2.1115

Orbigny, A. D'. 1842-1843. Paléontologie franc saise, terrains Crétacés, Tome II. Gastéropodes. 456 pp. Arthus Bertrand, Paris.

RAFINESQUE, C.S. 1815. Analyse de nature, ou tableau de l'univers et des corps organismes. 223 pp. L'auteur \& Jean Barravecchia, Palerme.

Romano, C., Goudemand, N., Vennemann, T.W., Ware, D., Schneebeli-Hermann, E., Hochuli, P.A., Brühwiler, T., BrinkmanN, W. \& BuCher, H. 2013: Climatic and biotic upheavals following the end-Permian mass extinction. Nature Geoscience 6, 57-60. DOI 10.1038/ngeo1667

SCHRÖDER, M. 1995. Frühontogenetische Schalen jurassischer und unterkretazischer Gastropoden aus Norddeutschland und Polen. Palaeontographica, Abteilung A 283, 1-95.

Valentine, J.W. 1986. The Permian-Triassic extinction event and invertebrate development modes. Bulletin of Marine Science 39, 607-615.

WAagen, W. 1895. Salt-Range fossils. Vol. II. Fossils from the Ceratite Formation. Part I. Pisces-Ammonoidea. Palaeontologia Indica 13(2), 1-323.

Ware, D., Bucher, H., Brayard, A., Schneebeli-Hermann, E. \& BRÜHWILER, T. 2015. High-resolution biochronology and diversity dynamics of the Early Triassic ammonoid recovery: the Dienerian faunas of the Northern Indian Margin. Palaeogeography, Palaeoclimatology, Palaeoecology 440, 363-373. DOI 10.1016/j.palaeo.2015.09.013

Ware, D., Bucher, H., Brühwiler, T., Schneebeli-Hermann, E., Hochuli, P.A., Roohi, G., uR-Rehman, K. \& Yaseen, A. in press. Griesbachian and Dienerian (Early Triassic) ammonoids from the Salt Range, Pakistan. Fossils and Strata.

WArén, A. \& Bouchet, P. 1993. New records, species, genera, and a new family of gastropods from hydrothermal vents and hydrocarbon seeps. Zoologica Scripta 22, 1- 90.

DOI 10.1111/j.1463-6409.1993.tb00342.x 
Warén, A. \& Bouchet, P. 2009. New gastropods from deep-sea hydrocarbon seeps off West Africa. Deep Sea Research 56, 2326-2349. DOI 10.1016/j.dsr2.2009.04.013

WARÉN, A., GoFAS, S. \& SCHANDER, C. 1993. Systematic position of three European heterobranch gastropods. The Veliger 36, 1-15.

Wasmer, M., Hautmann, M., Hermann, E., Ware, D., Roohi, G., ur-Rehman, K., Yaseen, A. \& Bucher, H. 2012. Olenekian (Early Triassic) Bivalves from the Salt Range and Surghar Range, Pakistan. Palaeontology 55, 1043-1073.

DOI 10.1111/j.1475-4983.2012.01176.x

WheELEy, J.R. \& TwitchetT, R.J. 2005. Palaeoecological significance of a new Griesbachian (Early Triassic) gastropod assemblage from Oman. Lethaia 38, 37-45.

DOI 10.1080/0024116051003150
White, C.A. 1874. Preliminary report upon invertebrate fossils collected by the expeditions of 1871,1872 , and 1873, with descriptions of new species. Geographical Surveys West of the $100^{\text {th }}$ Meridian (U.S.), 1-27.

WittenbuRg, P. von 1908. Beiträge zur Kenntnis der Werfener Schichten Südtirols. Geologische und Palaeontologische Abhandlungen 8(5), 251-289.

WöHrmann, S. \& KoKEn, E. 1892. Die Fauna der Raibler Schichten vom Schlernplateau. Zeitschrift der Deutschen Geologischen Gesellschaft 44, 167-223.

Yochelson, E.L. \& SAunders, B.W. 1967. A bibliographic index of North American Late Paleozoic Hyolitha, Amphineura, Scaphopda, and Gastropoda. Geological Survey Bulletin 1210, 1-271. 